\title{
Research on Economic Value Added based on Financial Strategy Matrix A Case Study of Nonferrous Metals Industry
}

\author{
Hanyue Xiao ${ }^{1, a^{*}}$ and Mingran Deng ${ }^{2, b}$ \\ 1.School of management, Wuhan university of technology,Wuhan,Hubei, 430070, China \\ 2.School of management,Wuhan university of technology,Wuhan,Hubei, 430070, China \\ 178477231@qq,com;dmr@whut.edu.cn
}

Keywords: Economic Value Added(EVA); Financial strategy matrix; Nonferrous metals industry

\begin{abstract}
The objective of this paper is to make a research about present value-creating ability of listed companies in non-ferrous metals industry. There are 52 listed companies in non-ferrous metals industry taken as research samples to estimate the Economic Value Added (EVA) from 2013 to 2015. Based on the EVA information of 2015, financial strategy matrix is used as a method to classify these sample companies into four types. The results indicate that the non-ferrous metals industry has low ability of value creation. Some financial strategy suggestions are put forward for the distributed companies in four different quadrants.
\end{abstract}

\section{Introduction}

With the global economic downturn and the "new normal" of Chinese economy, the non-ferrous metals industry is going to the winter, and faced with the situation of rectification and change[1]. Due to the adverse effects of domestic and foreign macroeconomic, tin, copper, zinc and other non-ferrous metals prices continued to fall. In addition, the rise of electricity, energy, labor and other cost elements make profit margins eroded. At the same time, the construction industry, automobile, home appliances and other non-ferrous metals downstream industry demand is also in the downturns because of the bad macroeconomic, the downstream demand reduction in the color industry has caused serious overcapacity, oversupply and prices fell further[2]. With the not optimistic macro environment, how non-ferrous metals enterprises adjust the corporate financial strategy to obtain a new round of value growth in the industry change?

\section{An Explanation of Value Assessment Tools}

Economic Value Added, as a value assessment method, has greater advantage than the traditional financial evaluation methods[3]. Based on the principle of accrual basis, the traditional financial evaluation index can not effectively reflect the real situation of the enterprise, especially in the calculation of the capital cost of the enterprise. EVA takes capital costs for more consideration and has more practical significance[4]. In the EVA calculation, the accounting profit adjustment, the elimination of data distortion, from the profitability and operation of two angles to promote capital utilization and profitability, the value of corporate creation to better reflect[5].

Financial strategy matrix is a tool to analyze the growth of enterprise value, emphasizing the value of the creation, and the biggest advantage of this financial tool is to guide business managers to pay more attention in cost control, more efficient in use of assets to gain higher return on investment [6]. The financial strategy matrix is a coordinate system that takes the ROIC-WACC as the ordinate and the difference between the sales growth rate and the sustainable growth rate as the abscissa. This matrix can be simplified to EVA as the ordinate and the cash flow as the abscissa[7]. 


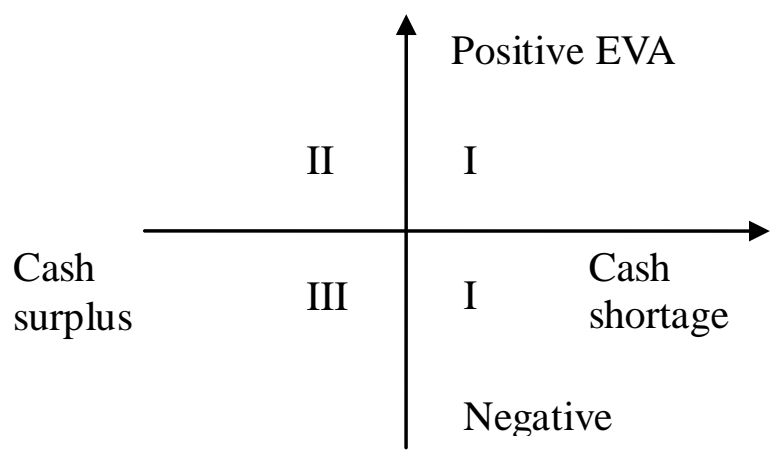

Figure 1

\section{Empirical Study Results and Analysis}

Sample selection and data sources. This paper chooses the financial data of 52 listed companies in Shanghai and Shenzhen stock markets as the research samples, calculates and analyzes the EVA and cash flow of the enterprises. Then the financial strategy matrix is used to classify the sample companies based on the data of 2015. Some listed companies are excluded that existing the ST, abnormal fluctuations during the inspection of the main indicators of in the data and the lack of data. The relevant financial data of listed companies are derived from Guotaian database.

The Statistical Results and Analysis.

Table 1

\begin{tabular}{|c|c|c|}
\hline Year & Net Income & EVA \\
\hline 2013 & 275486586.55 & -211440250.13 \\
\hline 2014 & -173788790.20 & -347095175.40 \\
\hline 2015 & -56469403.29 & -320834508.10 \\
\hline Mean value & 15076131.02 & -293123311.21 \\
\hline
\end{tabular}

From Table 1, entering 2014, the profits of non-ferrous metals industry slumped and suffered a loss. The main reason is that after entering the new economic normal, the downstream demand dropped, overcapacity, some companies to reduce production. In 2015, Supply-side structural reform has been effective, non-ferrous metals prices rose, profits have rebounded, but still negative. In 2013, the average net profit of the sample was -1.74 billion yuan, and the EVA average was -2.11 billion yuan, which was reduced by $177 \%$. The data of 2014 and 2015 have the similar results.

The results show that there are significant differences between performance and traditional profit indicators, EVA values are significantly lower than the net profit value in every year. It can be seen that the traditional profit indicators overestimate the performance level of the management to a large extent by not considering the cost of equity capital and the related adjustment items. Generally speaking, non-ferrous metals industry has low value creation ability.

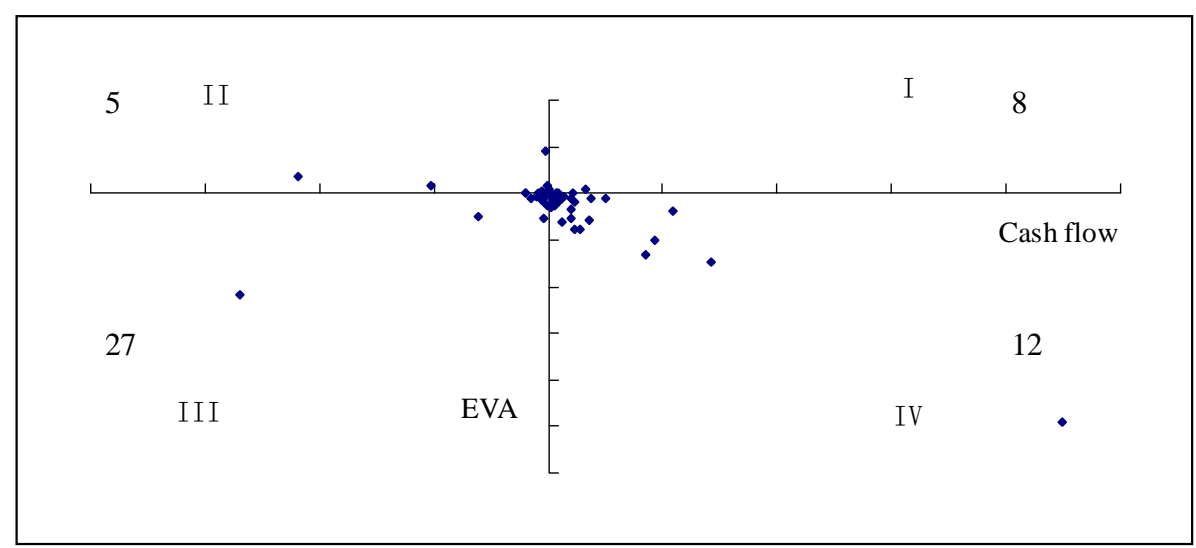

Figure 2 
From the figure 2, it can clearly see that most companies are in the third quadrant and the fourth quadrant in the financial strategy matrix. The listed companies in the quadrant III are most, accounting for $51.9 \%$ of the sample; the quadrant IV has 12 companies, accounting for $23.1 \%$ of the sample; the quadrant I and quadrant II accounted for $15.4 \%$ and $9.6 \%$ of the sample size respectively.

In terms of value performance, $75 \%$ of the sample enterprises have negative EVA, indicating that the overall value of non-ferrous metals industry is low and listed companies in China's non-ferrous metals industry have a common problem of corporate value reduction, in the stage of the need for industrial upgrading and transformation. In the state of funds, the enterprises with the remaining funds accounted for $61.5 \%$ of the sample size, indicating that non-ferrous metals listed companies did not make full use of existing funds, and has high corporate capital costs and low capital usage efficiency.

\section{Proposed Measures}

The quadrant I: value-added cash shortages. In the quadrant I, sample companies have positive EVA and negative cash flow, such enterprises are good at creating value, but the cash flow is not enough to support business growth. The primary problem of this kind of companies is to solve the shortage of funds and increase cash inflows to maintain the implementation of business operations[8]. They can improve operational efficiency and adjust the financial policy to improve sustainable growth rate; then increasing equity capital.

As for financing strategies, external financing strategies such as debt financing and equity financing should be adopted. Enterprises can increase borrowings and find new shares to finance, but cannot affect their value of the creation because of the capital structure. As for investment strategies, enterprises should avoid blind expansion, but increase the core business investment and improve core competitiveness, while giving up products that have slow turnover and low profit margins. As for distribution, companies need to reduce the distribution of dividends to increase cash flow to meet the value of the creation of investment activities.

The quadrant II: value-added cash surplus. In the quadrant II, sample companies have positive EVA and positive cash flow, such enterprises can bring value to the enterprise value, while the cash flow can meet the development needs. It is the best situation of the four quadrants. Such enterprises may face underdevelopment, and should use surplus cash to accelerate growth.

As for financing strategy, both internal and external financing can be used. If there is no special high-quality investment projects, earnings and stock financing way should be retained to prevent enterprises facing huge amounts of debt, especially to avoid the "short-term investment." [9] As for investment strategy, enterprises in the quadrant should take a diversified investment strategy and avoid excessive concentration of capital in an industry risk, such as participation in high-quality municipal engineering construction. As for distribution, such enterprises should take a fixed or stable growth of the dividend distribution strategy, give the corresponding return of shareholders and establish a good corporate image.

The quadrant III: value-diminished cash surplus. In the quadrant II, sample companies have negative EVA and positive cash flow, such enterprises can generate enough cash flow to maintain their own development, but the business growth will reduce the value of the enterprise. These enterprises must reconstruct the corresponding financial strategy as soon as possible, if unable to refactoring, should immediately give them up.

As for financing strategies, such enterprises have retained cash and should adopt a conservative financing strategy. Equity capital has not been effectively used may cause the negative EVA. As for investment strategy, the existing business not only cannot bring value, but continues to erode the value of shareholders. Companies should improve the rate of return on investment, using existing capital surplus to expand market share, price increases, while controlling costs to improve operating margins. This requires companies to produce competitive high value-added products, increase $\mathrm{R} \&$ $\mathrm{D}$ costs, which can effectively improve the EVA value[10]. As for distribution, although there are 
retained funds, these enterprises have unstable earnings and high debt, so need to take a low-income distribution strategy, low or no dividend policy.

The quadrant IV: value-diminished cash shortage. In the quadrant IV, sample companies have negative EVA and negative cash flow, the companies in the quadrant can not bring value added, and also lack sufficient funds to maintain the development of enterprises, which is the worst state. Such enterprises should make the enterprise assets realized as soon as possible to minimize the loss. The measures that can be taken are asset reorganization or full sale of the business.

\section{Conclusion}

By measuring and calculating EVA of 52 listed companies in the non-ferrous metals industry, we found that the industry's overall value creation is not high and is in the stage of industrial upgrading and transformation. Therefore, this paper classifies the sample companies through the financial strategy matrix, and puts forward different financial improvement strategies for the four types of companies in different quadrants, which can be a guide for the non-ferrous metals industry seeking the way out of the overall environment.

At the same time, the EVA-based financial strategy matrix evaluation system adopted in this paper also has limitations in the business. EVA is still a single data index rather than a comprehensive financial indicators and can not get rid of the lagging accounting data lag; EVA-based financial strategy Matrix depends on the information disclosure system, which is vulnerable to accounting; EVA reflects the intrinsic value of the enterprise. In the current capital market conditions, it shows a static indicator, not taking into account the government, non-financial factors and market factors. EVA evaluation system emphasizes more on the ability of sustainable development than the traditional financial evaluation. With the continuous improvement of China's capital market development, EVA-based financial strategy matrix in the enterprise financial management will be more widely used.

\section{References}

[1]Liu Yongxiang. Research on EVA Performance of Non - ferrous Metal Industry Listed Companies in China [J]. Economic Research Reference, 2012 (63): $45 \sim 50$.

[2]Xie Jinlian. New thinking on the healthy development of non - ferrous metals industry [J]. Enterprise Science and Technology Development, 2016 (4): $142 \sim 144$.

[3]Liu Zhiyuan. Corporate Financial Strategy [M]. Northeast University of Finance and Economics Press, 1997.

[4]Jiang Gaoyang. Research on financial strategy based on EVA value management [J]. Accounting and learning, 2016 (21): $45 \sim 46$.

Li Hong, Zhang Deming, Cao Xiuying and so on. An Empirical Study on the Effectiveness of EVA [5]Performance Evaluation Index - Based on the Data of 454 Listed Companies in 2004 [J]. China Soft Science, 2006 (10): $150 \sim 157$.

[6]Cao Wei, Ye Ming, Zhao Can. Discussion on the Application of Financial Strategy Matrix in Enterprises - Taking China Resources as an Example [J]. Friends of Accounting, 2012 (7): 38 40.

[7]Ruth Bender, Keith Ward. Corporate Finance Strategy [M]. Beijing: People's Posts and Telecommunications Press, 2003.

[8]Wei Minghai. Financial strategy: an analysis of the impact of cyclical factors [M]. China Finance and Economics Press, 2001.

[9]Li Jie, Chen Lu. Construction of Performance Model of Listed Companies Based on Entropy Method - Taking Nonferrous Metals Industry as an Example [J]. Finance and Accounting, 2014 (14): $25 \sim 27$.

[10]Yanjing pool. Analysis on the influence of supply side reform on the development of nonferrous metals industry in China [J]. China Metal Bulletin, 2016 (8): $66 \sim 67$. 